\title{
Tolerance to salinity of chicory plants grown in hydroponics
}

\author{
Tolerância do almeirão à salinidade em cultivo hidropônico
}

\begin{abstract}
Jerônimo Luiz AndrioloI José Carlos Cazarotto Madalóz ${ }^{\mathrm{II}}$ Rodrigo dos Santos Godoi ${ }^{\mathrm{II}}$ Djeimi Isabel Janisch ${ }^{\text {II }}$ Cláudia Alessandra Peixoto de Barros ${ }^{\text {II }}$
\end{abstract}

\begin{abstract}
Chicory plants, cv. 'Amarelo' and 'Pão de Açúcar', ABSTRACT were grown hydroponically under four $\mathrm{NaCl}$ concentrations in the nutrient solution to determine its tolerance to salinity. Sowing was made in rows placed $0.05 \mathrm{~m}$ apart, on a $0.15 \mathrm{~m}$ deep sand growing bed placed over fibber cement tiles. After emergence, plants were thinned to a plant density of 1,600plants $\mathrm{m}^{-2}$. A standard nutrient solution was used, with the main composition of, in mmol L-1 $13.5 \mathrm{NO}_{3}^{-} ; 2.5 \mathrm{NH}_{4}^{+}$; $1.5 \mathrm{H}_{2} \mathrm{PO}_{4}^{-} ; 1.5 \mathrm{SO}_{4}^{--}$; 7.5 $\mathrm{Ca}^{++} ; 10.0 \mathrm{~K}^{+}$and $1.5 \mathrm{Mg}^{++}$. The control (T1) was the standard nutrient solution, without addition of $\mathrm{NaCl}$. Four salinity levels were compared, by adding 0.697 (T2), 1.627 (T3), 2.556 (T4) and 3.485 (T5) $\mathrm{L} \mathrm{L}^{-1}$ of $\mathrm{NaCl}$. The nutrient solution was delivered to plants four times a day, in a closed system. A completely split plot randomised experimental design was used, with four replications. Plants were harvested at 31 days after sowing, by cutting the shoot at $0.02 \mathrm{~m}$ height. Fresh and dry mass of both cultivars decreased linearly by effect of salinity. For similar values of electrical conductivity, the decrease in fresh mass was stronger in plants of the Amarelo cultivar. Adding $\mathrm{NaCl}$ to the nutrient solution is a technique that may be used to reduce the water content of chicory plants grown hydroponically.
\end{abstract}

Key words: Cichorium intybus, fertigation, nutrient solution, salt tolerance.

\section{RESUMO}

Quatro concentrações de $\mathrm{NaCl}$ na solução nutritiva foram empregadas para determinar a tolerância das cultivares de almeirão "Amarelo" e "Pão de Açúcar" à salinidade da solução nutritiva. A semeadura foi feita em fileiras distanciadas de 0,05m, em uma camada de areia de 0,15m de profundidade, distribuída sobre telhas de fibrocimento. Após a emergência foi efetuado o desbaste, mantendo-se uma densidade de 1.600plantas $\mathrm{m}^{-2}$. Foi empregada uma solução nutritiva com a composição de, em mmol L-1, 13,5 $\mathrm{NO}_{3}^{-} ; 2,5 \mathrm{NH}_{4}^{+} ; 1,5 \mathrm{H}_{2} \mathrm{PO}_{4}^{-}$; 1,5 $\mathrm{SO}_{4}^{-} ; 7,5 \mathrm{Ca}^{++} ; 10,0 \mathrm{~K}^{+}$e 1,5 $\mathrm{Mg}^{++}$. A testemunha (T1) foi a solução nutritiva descrita anteriormente, sem adição de $\mathrm{NaCl}$. Quatro níveis salinos foram comparados, mediante adição de 0,697 (T2), 1,627 (T3); 2,556 (T4) e 3,485 (T5)g L-1 de NaCl. A solução nutritiva foi fornecida quatro vezes ao dia, em sistema fechado. $O$ delineamento experimental inteiramente casualizado foi empregado com quatro repetições em parcelas subdivididas. A colheita foi realizada aos 31 dias após a semeadura, mediante corte da parte aérea das plantas a 0,02m de altura. A massa fresca e seca de ambas as cultivares decresceu por efeito da salinidade. Para níveis similares de condutividade elétrica, o decréscimo na massa fresca foi maior nas plantas da cultivar Amarelo. A adição de $\mathrm{NaCl}$ na solução nutritiva é uma técnica que pode ser empregada para reduzir o teor de água das plantas de almeirão em cultivo hidropônico.

Palavras-chave: Cichorium intybus, fertirrigação, solução nutritiva, tolerância à salinidade.

Chicory is a vegetable crop appreciated in typical gastronomy. Soil-grown production systems for this crop are being nowadays replaced by hydroponical techniques, to improve yield, quality and cleanness (FAQUIN \& FURLANI, 1999). Nevertheless, the fraction of dry matter in hydroponical grown vegetables is lower than in soil, leading plants to wilt quickly after harvest. High salinity nutrient solutions have been used to reduce vegetative growth and to increase leaf thickness and the fraction of dry matter of horticultural

'Departamento de Fitotecnia, Universidade Federal de Santa Maria (UFSM), 97105-900, Santa Maria, RS, Brasil. E-mail: andriolo@smail.ufsm.br. Autor para correspondência.

"Curso de Agronomia, UFSM, 97105-900, Santa Maria, RS, Brasil. 
crops (LI \& STANGUELLINI, 2001. Growing vegetables under saline conditions is also a matter of interest for using low quality water in irrigation and for re-using nutrient solutions from soilless culture (FLOWERS, 2004).

Water absorption is the first process affected by salinity, influencing water and ion uptake rates. Fresh growth is reduced more drastically than does dry mass, resulting in smaller leaves, shorter stature and sometimes fewer leaves (JACOBY, 1994; CUARTERO \& FERNÁNDEZ-MUÑOZ, 1999). In a comprehensive review about salt tolerance of vegetable species, SHANNON \& GRIEVE (1999) classified lettuce, carrot, onion and potato as high sensitive, with a threshold electrical conductivity (EC) of $2.0 \mathrm{dS} \mathrm{m} \mathrm{m}^{-1}$. By EC values upper than this threshold, a fresh yield decline of more than $10 \%$ per unit $\left(\mathrm{dS} \mathrm{m}^{-1}\right)$ of EC is expected. For the lettuce crop, AYERS et al. (1951) reported a threshold of $1.3 \mathrm{dS} \mathrm{m} \mathrm{m}^{-1}$ and a negative slope of $13 \%$, while calculated values by ANDRIOLO et al (2004) were $2.0 \mathrm{dS} \mathrm{m} \mathrm{m}^{-1}$ and $14.9 \%$, respectively. No data were found in the literature for the chicory crop.

The goal of this research was to determine the decline in growth and yield of chicory plants under increased salt concentration of the nutrient solution and to infer about its tolerance to salinity.

A closed hydroponical growing system made up inside a polyethylene tunnel was used, at the Universidade Federal de Santa Maria. Each experimental unit was $3.05 \mathrm{~m}$ length and $1.10 \mathrm{~m}$ width, with a slope of $3 \%$. Sand of $0.0015-0.003 \mathrm{~m}$ particle size was used to make up a $0.15 \mathrm{~m}$ depth growing bed (For more details about the experimental set-up, see Andriolo et al., 2004). The nutrient solution was pumped several times a day from a 200L plastic reservoir to the upper side of the growing bed. From there, it drained off across the bed back to the reservoir.

On November $11^{\text {th }}, 2005$, the cultivars ‘Amarelo' and 'Pão de Açúcar' were sowed directly on the growing bed, in rows $0.05 \mathrm{~m}$ apart. At the two-leaves stage, a plant density of 1,600 plants $\mathrm{m}^{-2}$ was retained, by manually picking out smaller plantlets. Water and nutrients were supplied by means of a standard nutrient solution with the following composition, in mmol $\mathrm{L}^{-1}$ : $13.5 \mathrm{NO}_{3}^{-} ; 2.5 \mathrm{NH}_{4}^{+} ; 1.5 \mathrm{H}_{2} \mathrm{PO}_{4}^{-} ; 1.5 \mathrm{SO}_{4}^{--} ; 7.5 \mathrm{Ca}^{++} ; 10.0$ $\mathrm{K}^{+}$and $1.5 \mathrm{Mg}^{++}$, and, in $\mathrm{mg} \mathrm{L}^{-1}$, $0.42 \mathrm{Mn}$; 0.26 Zn; 0.05 $\mathrm{Cu} ; 0.50 \mathrm{~B} ; 0.04 \mathrm{Mo}$, and 4.82 chelated Fe. The $\mathrm{pH}$ and electrical conductivity was 5.8 and $2.9 \mathrm{dS} \mathrm{m} \mathrm{m}^{-1}$, respectively. The pump delivered the nutrient solution for 15 minutes, at intervals of 90 minutes during the day and 420 minutes during the night. The tunnel was ventilated on sunny days by opening the lateral sides, to reach similar values of maximum air temperatures inside and outside of it.
The control (T1) was the standard nutrient solution described above, without addition of $\mathrm{NaCl}$. Four salinity levels were compared, by adding 0.697 (T2), 1.627 (T3), 2.556 (T4) and 3.485 (T5)g L ${ }^{-1}$ of NaCl, estimated by the relation $\mathrm{EC}\left(\mathrm{dS} \mathrm{m} \mathrm{m}^{-1}\right)=0.136+0.75 \mathrm{X}\left(\mathrm{g} \mathrm{L}^{-1}\right)$ previously determined in the laboratory. The EC values averaged over the experimental period were 3.0 ; 4.5 ; 6.3; 7.1 and $9.5 \mathrm{dS} \mathrm{m}^{-1}$, respectively. The EC and $\mathrm{pH}$ were daily measured. A volume of water or an aliquot of nutrient solution at the required concentration was added every time the measured EC was $10 \%$ above or below the original value, respectively. The volumes of the nutrient solution into the reservoir were estimated by a linear equation previously fitted between the volume and the depth of the liquid column into the reservoir. The $\mathrm{pH}$ was maintained in the range between 5.0 e 6.0 by additions of $\mathrm{H}_{3} \mathrm{PO}_{4}$ or $\mathrm{KOH}$, from a titration curve previously determined in the laboratory. A completely randomised split-plot experimental design was used, with four replications and an experimental set-up for each plot.

Plants were harvested at 31 days after sowing (DAS), by cutting the shoot at $0.02 \mathrm{~m}$ height. Fresh mass was determined after harvest and dry mass after drying at $60^{\circ} \mathrm{C}$ until constant dry weight was reached. Statistical models were fitted by regression analysis.

Fresh and dry mass of both cultivars decreased linearly by effect of salinity (Figure 1). For similar values of EC, the decrease in fresh mass was stronger in plants of the 'Pão de Açúcar' cultivar. These plants died at the EC of $9.5 \mathrm{dS} \mathrm{m} \mathrm{m}^{-1}$ in T5, while a decrease of about $94 \%$ was recorded in plants of 'Pão de Açúcar'. The reduction in fresh yield per unit of increase in the EC of the nutrient solution was of about $14 \%$ for 'Pão de Açúcar' and 16\% for 'Amarelo’. Similar patterns of decrease in dry mass were observed for both cultivars (Figure 1B). Any tip burn symptoms were observed in plants of all treatments.

The percent decline in fresh yield was higher than the 10\% reported by AYERS (1951) and similar to that of ANDRIOLO et al. (2004) for lettuce, under multiple concentrations of the nutrient solution. This suggests that saline effects on plant growth induced either by high concentrations of the nutrient solution or by $\mathrm{NaCl}$ is similar. Though genotypical effects could not be excluded, environmental variables are the main factor affecting the tolerance of plants to salinity and the reduction in fresh weight will be stronger under conditions of high plant water demand. As a consequence, it should be expected a more negative effect of salinity on yield in summer grown crops. In this way, the higher fresh weight reached by 'Pão de Açúcar' may be explained by the fact that this cultivar 

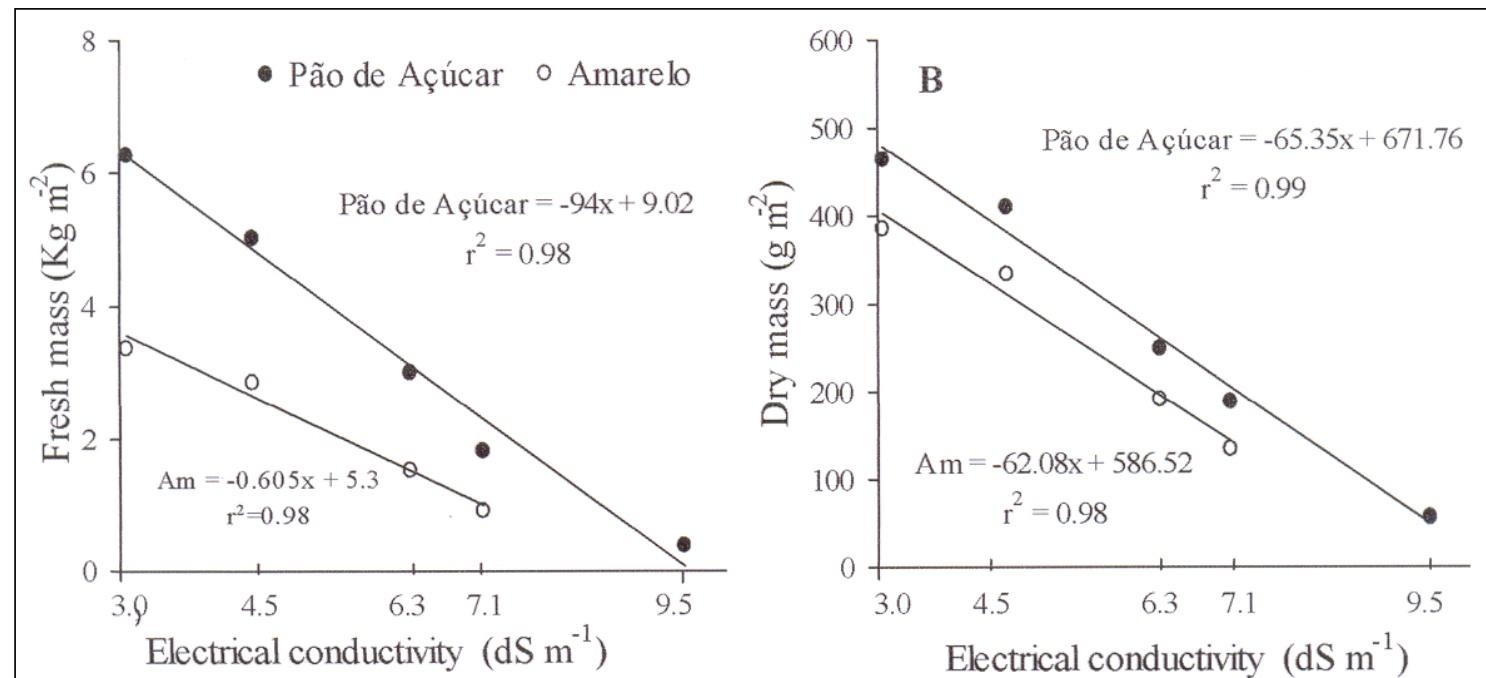

Figure 1 - Fresh (A) and dry (B) mass of chicory plants grown hydroponically under electrical conductivities of 3.0; 4.5; 6.3; 7.1 and $9.5 \mathrm{dS} \mathrm{m}^{-1}$ by addition of $\mathrm{NaCl}$ in the nutrient solution. Santa Maria, UFSM, 2005.

is of the head type, in which inner leaves are protected against environmental factors controlling the plant water flux, such solar radiation and air saturation deficit.

Based on present results, the chicory crop may be included in the high sensitivity group of SHANNON \& GRIEVE’S (1999) classification. For the 'Pão de Açúcar cultivar', adding $\mathrm{NaCl}$ to the nutrient solution is a technique that may be used to reduce the water content of plants. A decrease of $1.567 \mathrm{~g} \mathrm{~m}^{-2}$ in fresh mass may be expected for each $\mathrm{gL}^{-1}$ of $\mathrm{NaCl}$ added in the nutrient solution.

\section{ACKNOWLEDGEMENTS}

To Fundação de Amparo a Pesquisa do Estado do Rio Grande do Sul (FAPERGS), for a grant to José Carlos Cazarotto Madalóz and Conselho Nacional de Desenvolvimento Científico e Tecnológico (CNPq)

\section{REFERENCES}

ANDRIOLO, J.L. et al. Cultivo hidropônico da alface empregando substratos: uma alternativa a NFT?. Horticultura Brasileira, v.22, n.4, p.794-798, 2004.
AYERS, A.D. et al. Salt tolerance of six varieties of lettuce. Proceeding of American. Society for Horticultural Science, v.57, p.237-242, 1951.

CUARTERO, J.; FERNÁNDES-MUÑOZ, R. Tomato and salinity. Scientia Horticulturae, v.78, p.83-125, 1999.

FAQUIN, V.; FURLANI, P.R. Cultivo de hortaliças de folhas em hidroponia em ambiente protegido. Informe Agropecuário, v.20, n.200/201, p.99-104, 1999.

FLOWERS, T.J. Improving crop salt tolerance. Journal of Experimental Botany, v.55, n.396, p.307-319, 2004.

JACOBY, B. Mechanisms involved in salt tolerance by plants. In: PESSARAKLI, M. (Ed.). Handbook of plant and crop stress. New York: Marcel Dekker, 1994. p.97-123.

LI, Y.L.; STANGUELLINI, C. Analysis of the effect of EC and potential transpiration on vegetative growth of tomato. Scientia Horticulturae, v.89, p.9-21, 2001.

SHANNON, M.C.; GRIEVE, C.M. Tolerance of vegetable crops to salinity. Scientia Horticulturae, v.78, p.5-38, 1999. 